Physicochemical Properties of Biochar Derived from Agricultural and Forestry Processing Wastes as Cultural Medium Substance and Its Effect on Growth Quality of Vegetable Plug Seedlings

KU0, We i - Ru

Department of Horticulture, College of Agriculture, National Chiayi University | Laboratory of Wood Material Technology, Division of Sustainable Bioresources Science, Department of Agroenvironmental Sciences, Faculty of Agriculture, Kyushu University

HUANG, Jian-Jhong

Graduate Institute of Wood Based Materials and Design, College of Agriculture, National Chiayi University | Laboratory of Wood Material Technology, Division of Sustainable Bioresources

Science, Department of Agro-environmental Sciences, Faculty of Agriculture, Kyushu University

FUJIM0T0, Noboru

Laboratory of Wood Material Technology, Division of Sustainable Bioresources Science, Department of Agro-environmental Sciences, Faculty of Agriculture, Kyushu University

LIN, Han Chien

Laboratory of Environment Functional Materials, Department of Wood Based Materials and Design, College of Agriculture, National Chiayi University | Laboratory of Wood Material Technology, Division of Sustainable Bioresources Science Department of Agro-environmental Sciences, Faculty of Agriculture, Kyushu University

https://doi.org/10.5109/1955655

出版情報: 九州大学大学院農学研究院紀要. 63 (2), pp.361-370, 2018-09-01. Faculty of Agriculture, Kyushu University

バージョン :

権利関係 : 


\title{
Physicochemical Properties of Biochar Derived from Agricultural and Forestry Processing Wastes as Cultural Medium Substance and Its Effect on Growth Quality of Vegetable Plug Seedlings
}

\author{
Wei-Ru KUO ${ }^{1}$, Jian-Jhong HUANG ${ }^{2}$, Noboru FUJIMOTO ${ }^{3}$ and Han Chien LIN ${ }^{4 *}$ \\ Laboratory of Wood Material Technology, Division of Sustainable Bioresources Science, \\ Department of Agro-environmental Sciences, Faculty of Agriculture, \\ Kyushu University, Fukuoka 812-8581, Japan \\ (Received May 1, 2018 and accepted May 8, 2018)
}

\begin{abstract}
This study used biochar derived from agricultural and forestry processing wastes as a portion of culture medium to investigate its effect on the growth quality of vegetable plug seedlings. The yield of biochars was $31.02-89.02 \%$, the content of element C was 18.94-85.79\%, the Japanese cedar sawdust biochar (JCSBC) had the highest content, followed by the sorghum distillery residue biochar (SDRBC). The SDRBC had higher $\mathrm{N}$ content (6.46-11.73\%), and its $\mathrm{pH}$, iodine value, and electrical conductivity (EC) were $6.53-8.74,71.01-210.33 \mathrm{mg} / \mathrm{g}$, and $0.10-0.37 \mathrm{ds} / \mathrm{m}$. The FTIR results of the SDRBC and cultivation waste bag biochar (CWBBC) in the spectrum had more $\mathrm{C}-\mathrm{H}$ stretching vibration hydrophilic functional groups at $2875 \mathrm{~cm}^{-1}$ and $2995 \mathrm{~cm}^{-1}$ than these of JCSBC or pulp sludge biochar (PSBC). The air-filled porosity, container capacity, and total porosity of the culture medium with biochar were 9.71-13.79\%, $61.27-63.11 \%$, and $70.02-74.01 \%$. The $\mathrm{pH}$ was $6.34-6.87$, and the EC was $0.96-1.22 \mathrm{ds} / \mathrm{m}$, approaching the requirements for general perfect medium. According to the growth quality results of Cucumis sativus plug seedlings, on Day 28 after seeding, the seedling index I and II of the peat with perlite were 0.1379 and 0.2790 , respectively; both with SDRBC were the highest at the carbonization temperature of $450^{\circ} \mathrm{C}$ (SDRBC-450), which were 0.1654 and 0.3376 , significantly different from the peat with perlite and other biochar media. Moreover, because the SDRBC-450 had higher cation exchange capacity (CEC) than the others in day of seedling period during cultivation, the vegetable plug seedlings had better growth quality.
\end{abstract}

Key words: Agricultural and Forestry Processing Wastes, Biochar, Culture Medium, Plug Seedling, Seedling Index

\section{INTRODUCTION}

Biomass wastes are the most abundant renewable organic resources on earth (Balat and Ayar, 2005), such as agricultural and forestry processing wastes (AFPW). According to statistics, Taiwan's annual output of AFPW is about 1.28 million MT (Agricultural statistics, 2012). The sorghum distillery residue, cultivation waste bag, forestry waste, and pulp sludge are characterized by easy procurement, low price, and large quantity, and the carbonization technology, which places biomass wastes in oxygen-free environments for low temperature pyrolysis, has been gradually applied. One of the products of this preparation is biochar, which is a porous material with high carbon content, an aerobic functional group, and aromatic compounds (Kolodynska et al., 2012; Regmi et al., 2012; Shrestha et al., 2010; Jiang et al., 2012; Yu et al., 2009).

\footnotetext{
${ }^{1}$ Department of Horticulture, College of Agriculture, National Chiayi University, Chiayi, Taiwan, ROC.

${ }^{2}$ Graduate Institute of Wood Based Materials and Design, College of Agriculture, National Chiayi University, Chiayi, Taiwan, ROC.

Laboratory of Wood Material Technology, Division of Sustainable Bioresources Science, Department of Agroenvironmental Sciences, Faculty of Agriculture, Kyushu University, Japan.

${ }^{4}$ Laboratory of Environment Functional Materials, Department of Wood Based Materials and Design, College of Agriculture, National Chiayi University, Chiayi, Taiwan, ROC.

* Corresponding author (E-mail: alexhlin@mail.ncyu.edu.tw)
}

Using biochar in agriculture is one of the popular environmental resource subjects at present, and is regarded as a soil improvement material due to its porosity and absorbability, which improves the physical and chemical properties of soil, enhances the soil structure, aggregates stability and water conductivity, absorbs soil heavy metal ions and organic contaminants, increases the microbial activity in the soil, reduces nutrient leaching loss, promotes plant growth, and enhances soil carbon sequestration (Joseph et al., 2010; Lehmann and Joseph, 2009). Furthermore, biochar has a wide range of feedstock, including cellulose, hemicellulose, lignin, mineral constituents, protein, carbohydrates, and other extracts. The cellulose, hemicellulose, and lignin can determine the content of volatile matter and fixed carbon in the pyrolysis, and influence the final chemical composition and structure of biochar (Joseph et al., 2007). Lua et al., (2004) mentioned that, when the pyrolysis temperature increases from 250 to $500^{\circ} \mathrm{C}$, the released volatile matter increases, which promotes the formation of pores in the biochar structure; thus, the specific surface area is enlarged, and the value of cation exchange capacity (CEC) and $\mathrm{pH}$ value increase. In the agricultural applications, the $\mathrm{pH}, \mathrm{CEC}$ value, and water retaining capacity of soil with biochar are enhanced (Glaser et al., 2002). In addition, the application of biochar improves the availability of moisture and mineral constituents during crop growth. With an appropriate biochar addition, the nutrient content in soil increases, which is absorbed by crops to increase the yield (Hidetoshi et al., 2009). The sur- 
face area of internal pores is larger than other materials due to the porous structure resulted from the pyrolysis of biochar; therefore, the absorption effect is good, the organic contaminants in the soil can be absorbed, and the contaminant absorption of crops is reduced (Yu et al., 2009). Tsakaldimi (2006) indicates that the three major functions of culture medium are water retention, nutrient preservation, and diffusion of oxygen to the root. The main constituents of general plug culture medium include peat, perlite (or vermiculite, sea sand) and a little organic substance or compound fertilizer. Peat accounts for $30-80 \%$ of the plug medium, it has strong waterholding capacity, high CEC, and mostly subacid $\mathrm{pH}$. The perlite increases the aeration degree of the medium, but it has no buffering power and very low CEC (Ho et al., 2011).

For sustainable utilization and environmentally friendly treatment of biomass wastes, and with the intention of developing an added value to wastes, this study used AFPW, including sorghum distillery residue, cultivation waste bags, Japanese cedar sawdust, and pulp sludge, as the feedstocks for preparing biochar at different carbonization temperatures. The physicochemical properties of the derived biochars were investigated. The biochar, as a cultural substrate to substitute perlite, was mixed with peat to form a culture medium for property analysis and plug seedlings. The investigations were also carried to evaluate the effect of biochar derived from AFPW as a portion of culture medium on the growth quality of vegetable plug seedlings.

\section{MATERIALS AND METHODS}

\section{Feedstock specimens and test materials}

Two types of agricultural processing wastes were as feedstocks, sorghum distillery residue (SDR) from $\mathrm{K}$ Liquor Inc., and cultivation waste bag (CWB) from Sinshe Township, Taichung County. And two sorts of feedstocks from forestry processing wastes were Japanese cedar thinning sawdust (JCS) from woodworking factory, NCYU, and pulp sludge (PS) from a paper mill, Cheng Loong Pulp, Taiwan. The feedstock specimens were pulverized to 5-10 mesh for future use.

Perlite was perlite \#4, produced by Taiwan Nan Hai Vermiculite Industrial Co. Ltd., which was over $55.16 \%$ with 5-10 mesh. The bamboo vinegar, collected at $80-150^{\circ} \mathrm{C}$, has been placed for 3 years, and diluted $10^{4}$ times as the irrigated solution use during the seedling period (Lin et al., 2011). Peat was Klasmann select peat, produced by the German Klasmann-Deilmann company, which was used as the main of cultural medium to be mixed with biochar, and its $\mathrm{pH}$ was 5.5-6.5. Cucumis sativus L. (cucumber), bought from the Known-You Seed Co., Ltd., was as the vegetable for seedling testing.

\section{Test methods}

Basic properties of feedstocks

For the elements analysis of feedstocks, an elements analyzer (Elementar vario EL) was used for measurement according to the NIEA R409.21C standard. For the chemical composition analysis, the alcohol-toluene extractives was measured according to the CNS4713 standard, the holocellulose content was measured according to the CNS 6948 standard, the lignin content was measured according to CNS 2721 and CNS 12108 standards, and the ash content was measured according to the CNS3084 standard.

Preparation and properties of biochar

The feedstocks were absolutely dried. About $20 \mathrm{~g}$ specimen was put in the crucible, and placed in a vertical high temperature activation furnace (Chi-How Heating Co., Ltd.). After vacuum pumping, the inside furnace was free of oxygen, carbonization was set at different temperatures $\left(200,250,300,350,400\right.$, and $450^{\circ} \mathrm{C}$ ) and the heating rate was $10 \mathrm{oC} / \mathrm{min}$. The nitrogen was put into the carbonization process, the gas flow was $200 \mathrm{~mL} / \mathrm{min}$, and the temperature was maintained for $60 \mathrm{~min}$. Finally, the nitrogen was flowed into the furnace for cooling to room temperature, and then the biochar specimen was taken out and weighed. The biochars (BC) were coded agricultural and forestry processing wastes biochar-carbonization temperature.

Biochar yield was calculated by yield (\%) = (oven dry weight of biochar/oven dry weight of feedstock) $\times 100$. $\mathrm{pH}$ value was measured by $\mathrm{pH}$ meter (SUNTEX TS-1) after the solution of various biochars with distilled water mixed in ratio of 1:5 (v/v\%) was kept still for $2 \mathrm{~h}$. Iodine value was evaluated according to JIS K 1474 (1991). The EC of each BC was same as the acid-alkali mixed solution ratio, measured by pen type EC meter (SUNTEX SC-120). For the Fourier transform infrared spectrum (FTIR) analysis, various biochars were pulverized, sieved through 20-40 mesh screen and completely dried in oven. The infrared spectrum was analyzed by Fourier transform infrared spectroscopy (Bio-Rad FTS40), the detector was the deterated triglycine sulphate (DTGS), the resolution was $4 \mathrm{~cm}^{-1}$, the number of scans was 64, the spectrum scanning area was $400-4000 \mathrm{~cm}^{-1}$, in order to analyze the surface functional group of feedstock and biochar.

Physicochemical properties of culture medium with biochar

For preparation of culture medium with biochar, various derived biochars were uniformly mixed with peat in a volume ratio of 15:85 (v/v\%) (Lin et al., 2010). The control group used commercially available peat and perlite. The physical properties of culture medium (Bragg and Chambers, 1988) with biochar were investigated. 1) Air-filled porosity (AFP): the drain hole in the bottom of the plug was covered, and the plug was placed in water bath, where the medium absorbed moisture from the bottom up till the plug surface was full of moisture. The plastic cushion clung to the plug bottom, the plug was removed from the water bath, placed on the scale, and weighed $\left(\mathrm{W}_{1}, \mathrm{~g}\right)$. Afterwards, the plug was removed and kept still to drain, and the medium surface was covered with preservative film to prevent the moisture from evaporating. The medium was weighed when it no longer drips $\left(\mathrm{W}_{2}, \mathrm{~g}\right)$, and AFP was calculated by equation. AFP $(\%)=\left(\mathrm{W}_{1}-\mathrm{W}_{2}\right) / \mathrm{V} \times 100 . \mathrm{V}(\mathrm{mL})$ was the volume of the 
plug full of moisture. 2) Container capacity (CC, also known as medium moisture capacity): the medium (W2) was placed in the oven cabinet and completely dried at $1050 \mathrm{C}$, and weighed after $24 \mathrm{~h}\left(\mathrm{~W}_{3}, \mathrm{~g}\right)$, and CC was calculated by equation. CC $(\%)=\left(\mathrm{W}_{2}-\mathrm{W}_{3}\right) / \mathrm{V} \times 100$. 3) Total porosity (TP): sum (\%) of AFP and CC. 4) Bulk density (BD): it was calculated from the weight $\left(\mathrm{W}_{3}\right)$ and volume of the completely dry medium.

In each seedling investigation, the culture media of three plugs were taken, and measured by $\mathrm{pH}$ measuring method (the same as the measurement of biochar properties). The culture media of another three plugs were taken for measuring EC. CEC was investigated from the culture media of the other three plugs that was placed in the oven cabinet and dried. The detail experimental steps of CEC refer to (Hendershot and Duquette, 1986). Plug seedling and biomass investigation

Biochars derived at different carbonization temperatures were used as the portion of culture medium, which was mixed with commercially available peat as the plug seedling medium, and the cucumber was used as the test vegetable. The seedlings were planted in the isolation chamber of the Department of Horticulture, Chiayi University on November 11, 2014. In the seedling period, in addition to general cultivation management, the seedlings were irrigated once every 7 days with nutrient solution Peters (Peters professional, Scotts Company, USA), which contained the ratio of nitrogen phosphorous and potassium being 20:20:20 and then was diluted 1000 times. In order to reach the $\mathrm{pH}$ range of the ideal culture media, they were irrigated with bamboo vinegar diluted $10^{4}$ times once every 3 days (Lin et al., 2011), the physicochemical properties of the culture medium and the seedling growth were investigated on the day following irrigation, and the plug seedling growth quality was evaluated according to the investigation of seedling index.

The growth quality of cucumber was investigated using the methods of Bilderback et al. (1982) and Fonteno (1990), when the seedlings have been cultivated for 1, 2, 3, and 4 weeks, six seedlings are randomly selected from the different processes for seedling investigation. The investigated items wereas follows:

1) Character, involving (a) stem length (cm): length of plant from the culture soil to the stem tip growing point; (b) stem diameter (mm): diameter of stem between the plant stems base and the top of cotyledon.

2) Mass, including (a) fresh weight of whole plant: the whole plant (including root system) was cleaned; (b) fresh weight of above-ground part: the stem base was cut off the plant, the surface moisture was sucked up by gauze; (c) fresh weight of underground part: the underground root system was cleaned of culture soil. The surface moisture of whole plant, above-ground part and underground part was individually sucked up by gauze, and the mass was weighed; (d) dry weight of whole plant: the whole plant (including root system) was placed in the kraft bag, dried in a $70^{\circ} \mathrm{C}$ oven for $48 \mathrm{~h}$, and the mass was weighed.

3) Two seedling indexes were used to evaluate the growth quality of vegetable seedlings. Seedling index I = (stem diameter/stem length) * dry weight of whole plant; Seedling index II = [(stem diameter/stem length $)+($ fresh weight of underground part/fresh weight of aboveground part)]*dry weight of whole plant.

\section{Statistical analysis}

The test results were represented by a mean (standard deviation), and the control group and test group were compared by Duncan's multiple range tests. If the $\rho$ value is smaller than 0.05 , meaning a significant difference between the test group and the control group, it is represented by different superscript upper case letters.

\section{RESULTS AND DISCUSSION}

\section{Basic properties of feedstocks}

The contents of $\mathrm{C}, \mathrm{N}, \mathrm{S}, \mathrm{H}$, and $\mathrm{O}$ elements in the agricultural processing waste SDR were 47.97, 3.31, 0.08, 6.51 , and $42.12 \%$, respectively, and those in CWB were individually $41.22,2.22,0.85,4.89$, and $50.81 \%$. The contents in the forestry processing waste JCS and PS were respectively $50.99,0.04,0.05,6.63,42.29 \%$, and $32.14,0.31,0.22,3.85,63.49 \%$. The SDR had the highest $\mathrm{N}$ content, and the four feedstocks had significant differences in accordance with Duncan's multiple range tests (Table 1). This is similar to the results of SDR (Diao et al., 2002; Lin et al., 2014) and JCS (Peng and Lin, 2015). These feedstocks can be regarded as potential biomass wastes for preparing biochar as the portion of culture medium.

Table 1. Elemental analysis of each feedstock

\begin{tabular}{ccccccc}
\hline Feedstock & & $\mathrm{C}(\%)$ & $\mathrm{N}(\%)$ & $\mathrm{S}(\%)$ & $\mathrm{H}(\%)$ & $\mathrm{O}(\%)^{1)}$ \\
\hline $\begin{array}{c}\text { Agriculture Processed } \\
\text { Residue }\end{array}$ & $\mathrm{SDR}^{2)}$ & $47.97(0.25)^{\mathrm{c})}$ & $3.31(0.08)^{\mathrm{d}}$ & $0.08(0.01)^{\mathrm{a}}$ & $6.51(0.13)^{\mathrm{c}}$ & $42.12(0.41)^{\mathrm{a}}$ \\
& CWB & $41.22(0.65)^{\mathrm{b}}$ & $2.22(0.05)^{\mathrm{c}}$ & $0.85(0.30)^{\mathrm{b}}$ & $4.89(0.08)^{\mathrm{b}}$ & $50.81(0.83)^{\mathrm{b}}$ \\
\hline $\begin{array}{c}\text { Forestry Processed } \\
\text { Residue }\end{array}$ & JCS & $50.99(0.43)^{\mathrm{d}}$ & $0.04(0.01)^{\mathrm{a}}$ & $0.05(0.09)^{\mathrm{a}}$ & $6.63(0.22)^{\mathrm{c}}$ & $42.29(0.71)^{\mathrm{a}}$ \\
& PS & $32.14(0.58)^{\mathrm{a}}$ & $0.31(0.17)^{\mathrm{b}}$ & $0.22(0.07)^{\mathrm{a}}$ & $3.85(0.47)^{\mathrm{a}}$ & $63.49(0.52)^{\mathrm{c}}$ \\
\hline
\end{tabular}

1) $\mathrm{O}(\%)=100-(\mathrm{C}+\mathrm{N}+\mathrm{S}+\mathrm{H})$

${ }^{2}$ SDR: sorghum distillery residue; CWB: cultivation waste bag; JCS: Japanese cedar sawdust; PS: pulp sludge

${ }^{3}$ Mean (standard deviation) with the different superscripts at the same element is significantly different $(p<0.05)$ by Duncan's multiple range tests 
The holocellulose content in the chemical composition of various feedstocks (Table 2) was 34.79-68.40\%; the CWB had the highest holocellulose content. This is because it is the waste from papermaking. PS had the lowest content. Its main composition is holocellulose, and it is generally treated by coagulant sedimentation. The lignin content was 18.29-34.63\%, the JCS was the highest, and PS was the lowest. P. Carrott and M. Carrott (2007) indicate that lignin has high carbon, its molecular structure is similar to soft coal, the charcoal is formed mainly from lignin and cellulose, and the hemicellulose is a volatile matter. Therefore, the higher the lignin, the higher the charcoals yield (Reed and Williams, 2004). The alcohol-toluene extractives in the four feedstocks were $1.59-13.12 \%$, and SDR had the highest content. The alcohol-toluene extractives consist of resin, wax, and tannin, and it influences the yield in the carbonization process (Peng and Lin, 2015). The SDR had high alcohol-toluene extractives because the sorghum husk contains tannin (Awika and Rooney, 2004). The ash was 0.63-7.73\%, CWB had the highest content, and JCS had the minimum content. It may be because the CWB has a

Table 2. Basic chemical compositions of each feedstock

\begin{tabular}{cccccc}
\hline \multirow{2}{*}{ Feedstock } & & Holecellulose (\%) & Lignin (\%) & $\begin{array}{c}\text { Eethanol-toluene } \\
\text { extractives (\%) }\end{array}$ & Ash (\%) \\
\hline $\begin{array}{c}\text { Agriculture Processed } \\
\text { Residue }\end{array}$ & SDR $^{1)}$ & $47.30(0.24)^{2)}$ & $31.50(0.34)$ & $13.12(0.52)$ & $6.05(0.50)$ \\
& CWB & $68.40(0.80)$ & $21.95(0.39)$ & $5.12(0.45)$ & $7.73(0.35)$ \\
\hline $\begin{array}{c}\text { Forestry Processed } \\
\text { Residue }\end{array}$ & JCS & $63.32(1.20)$ & $34.63(0.40)$ & $1.59(0.30)$ & $0.63(0.02)$ \\
& PS & $34.79(0.69)$ & $18.29(0.64)$ & $7.48(0.44)$ & $3.93(0.45)$ \\
\hline
\end{tabular}

${ }^{1)}$ see Table $1^{2)}$

${ }^{2)}$ Mean (standard deviation)

Table 3. Yield, $\mathrm{pH}$, iodine and $\mathrm{EC}$ values of various biochars

\begin{tabular}{|c|c|c|c|c|}
\hline Specimen $^{1)}$ & Yield (\%) & $\mathrm{pH}$ value & Iodine value (mg/g) & $\mathrm{EC}(\mathrm{ds} / \mathrm{m})$ \\
\hline SDRBC-200 & $70.02(0.02)^{\mathrm{a} 2)}$ & $6.53(0.04)^{\mathrm{a}}$ & $71.01(5.14)^{\mathrm{a}}$ & $0.37\left(0.11^{\mathrm{aa}}\right.$ \\
\hline SDRBC-250 & $51.05(0.03)^{\mathrm{b}}$ & $6.79(0.17)^{\mathrm{ab}}$ & $75.32(3.47)^{\mathrm{a}}$ & $0.28(0.13)^{\mathrm{ab}}$ \\
\hline SDRBC-300 & $42.01(0.01)^{c}$ & $7.25(0.01)^{\mathrm{b}}$ & $146.44(7.43)^{\mathrm{b}}$ & $0.21(0.08)^{\mathrm{b}}$ \\
\hline SDRBC-350 & $36.11(0.01)^{\mathrm{d}}$ & $7.94(0.13)^{\mathrm{b}}$ & $176.41(0.36)^{\mathrm{c}}$ & $0.10(0.04)^{\mathrm{c}}$ \\
\hline SDRBC-400 & $32.05(0.01)^{\mathrm{d}}$ & $8.27(0.08)^{c}$ & $193.02(5.85)^{\mathrm{cd}}$ & $0.11(0.01)^{\mathrm{c}}$ \\
\hline SDRBC-450 & $31.25(0.04)^{\mathrm{e}}$ & $8.74(0.04)^{c}$ & $210.33(6.85)^{\mathrm{d}}$ & $0.11(0.01)^{\mathrm{c}}$ \\
\hline CWBBC-200 & $88.35(0.02)^{\mathrm{a}}$ & $7.34(0.09)^{\mathrm{a}}$ & $130.05(7.42)^{\mathrm{a}}$ & $3.44(0.42)^{\mathrm{a}}$ \\
\hline CWBBC-250 & $76.40(0.01)^{\mathrm{ab}}$ & $8.08(0.04)^{\mathrm{ab}}$ & $136.69(7.56)^{\mathrm{a}}$ & $2.93(0.51)^{\mathrm{a}}$ \\
\hline CWBBC-300 & $64.06(0.04)^{\mathrm{b}}$ & $9.37(0.12)^{\mathrm{ab}}$ & $244.19(9.13)^{\mathrm{b}}$ & $2.26(0.34)^{\mathrm{a}}$ \\
\hline CWBBC-350 & $63.33(0.03)^{\mathrm{b}}$ & $10.34(0.07)^{\mathrm{b}}$ & $263.54(7.24)^{\mathrm{b}}$ & $1.79(0.23)^{\mathrm{b}}$ \\
\hline CWBBC-400 & $59.25(0.02)^{\mathrm{c}}$ & $10.97(0.02)^{\mathrm{bc}}$ & $326.30(8.02)^{c}$ & $1.92(0.27)^{\mathrm{bc}}$ \\
\hline CWBBC-450 & $54.60(0.02)^{\mathrm{c}}$ & $11.73(0.03)^{\mathrm{c}}$ & $341.39(9.50)^{\mathrm{d}}$ & $2.09(0.15)^{\mathrm{c}}$ \\
\hline JCSBC-200 & $75.43(0.02)^{\mathrm{a}}$ & $6.46(0.10)^{\mathrm{a}}$ & $42.54(7.71)^{\mathrm{a}}$ & $0.18(0.03)^{\mathrm{a}}$ \\
\hline JCSBC-250 & $41.30(0.01)^{\mathrm{b}}$ & $6.84(0.11)^{a}$ & $51.39(7.32)^{\mathrm{ab}}$ & $0.15(0.04)^{\mathrm{ab}}$ \\
\hline JCSBC-300 & $35.40(0.01)^{\mathrm{bc}}$ & $7.51(0.08)^{b}$ & $92.07(6.99)^{\mathrm{b}}$ & $0.12(0.08)^{b}$ \\
\hline JCSBC-350 & $32.06(0.01)^{c}$ & $8.05(0.10)^{c}$ & $104.39(6.44)^{\mathrm{b}}$ & $0.12(0.03)^{\mathrm{b}}$ \\
\hline JCSBC-400 & $30.49(0.02)^{\mathrm{cd}}$ & $8.28(0.04)^{\mathrm{cd}}$ & $139.45(9.04)^{c}$ & $0.07(0.01)^{c}$ \\
\hline JCSBC-450 & $28.88(0.01)^{\mathrm{d}}$ & $8.63(0.04)^{d}$ & $158.08(9.81)^{\mathrm{d}}$ & $0.07(0.02)^{\mathrm{c}}$ \\
\hline PSBC-200 & $89.35(0.01)^{\mathrm{a}}$ & $7.07(0.06)^{\mathrm{a}}$ & $145.64(0.47)^{\mathrm{a}}$ & $1.88(0.10)^{\mathrm{a}}$ \\
\hline PSBC-250 & $77.24(0.01)^{\mathrm{ab}}$ & $7.24(0.04)^{\mathrm{ab}}$ & $159.84(6.16)^{\mathrm{a}}$ & $0.51(0.05)^{\mathrm{b}}$ \\
\hline PSBC-300 & $70.05(0.02)^{\mathrm{b}}$ & $7.64(0.09)^{\mathrm{b}}$ & $184.06(7.14)^{\mathrm{a}}$ & $0.41(0.06)^{b}$ \\
\hline PSBC-350 & $69.38(0.01)^{\mathrm{b}}$ & $8.31(0.09)^{c}$ & $187.65(8.35)^{\mathrm{a}}$ & $0.77(0.01)^{\mathrm{c}}$ \\
\hline PSBC-400 & $66.41(0.04)^{\mathrm{bc}}$ & $9.03(0.10)^{\mathrm{d}}$ & $204.45(9.54)^{\mathrm{b}}$ & $0.45(0.02)^{\mathrm{d}}$ \\
\hline PSBC-450 & $65.60(0.01)^{\mathrm{c}}$ & $9.64(0.08)^{e}$ & $217.27(4.22)^{\mathrm{b}}$ & $0.40(0.01)^{\mathrm{e}}$ \\
\hline
\end{tabular}

${ }^{1)}$ see Table $1^{2)}$; BC-200: Biochar-carbonization temperature

${ }^{2)}$ Mean (standard deviation) with the different superscripts at the same specimen is significantly different $(p<0.05)$ by Duncan's multiple range tests 
high content of inorganic substance (Peng and Lin, 2015).

\section{Properties of derived biochars}

The yields of various biochars decreased as the carbonization temperature increased (Table 3). Teng and Hsu (1999) indicate that this is due to the volatile matter in the feedstock, tar dissipation, and the increased gasified quantity of carbon. Walker and Almagro (1995) indicate that the higher the carbonization temperature, the larger the gasified quantity, and in the pyrolysis, the $\mathrm{CO}, \mathrm{CH}_{4}$, formaldehyde, methanol, and hydrogen compounds are likely to form by degradation as the temperature increases. As shown in the Table 3, the four feedstocks were relatively subacid (6.46-7.34) at $200^{\circ} \mathrm{C}$. When the carbonization temperature was $450^{\circ} \mathrm{C}$, they became weakly alkaline or alkaline (8.63-11.73) as the temperature increased. When the feedstock is carbonized at high temperature, the organic compounds is decomposed by the heat, the different compounds are generated and discharged, while the inorganic matter remain, such as alkali metal elements $\mathrm{Ca}, \mathrm{K}$, and $\mathrm{Mg}$, and a higher temperature is required for the reaction to form oxides, which may be because its $\mathrm{pH}$ is subalkaline (Gundale and Deluca, 2006; Neary et al., 1999). Joseph et al. (2010) indicates that the soil pH suitable for plant growth is 6.5-7.5. Therefore, weakly alkaline or alkaline biochar can improve the $\mathrm{pH}$ of acid soil to promote the root system development of crops to increase crop yield. The iodine value of SDRBC was $71.01-210.33 \mathrm{mg} / \mathrm{g}$; that of CWBBC was $130.05-341.39 \mathrm{mg} / \mathrm{g}$; that of JCSBC was 42.54-158.08 mg/g; that of PSBC was $145.64-217.27 \mathrm{mg} / \mathrm{g}$. The EC is generally lower than $1 \mathrm{ds} / \mathrm{m}$ (Koranski, 1993). The results showed that the EC of various biochars decreased as the carbonization temperature increased. However, while the EC of CWBBC is higher than the other three, it is still in the comfort range for fruit vegetable seedlings (Norrie et al., 1994).

Table 4 shows the results of SDRBC elements analysis. The $\mathrm{C}$ content was $51.91-69.49 \%$. The $\mathrm{N}$ content was $3.17-4.66 \%$, and there was no significant difference
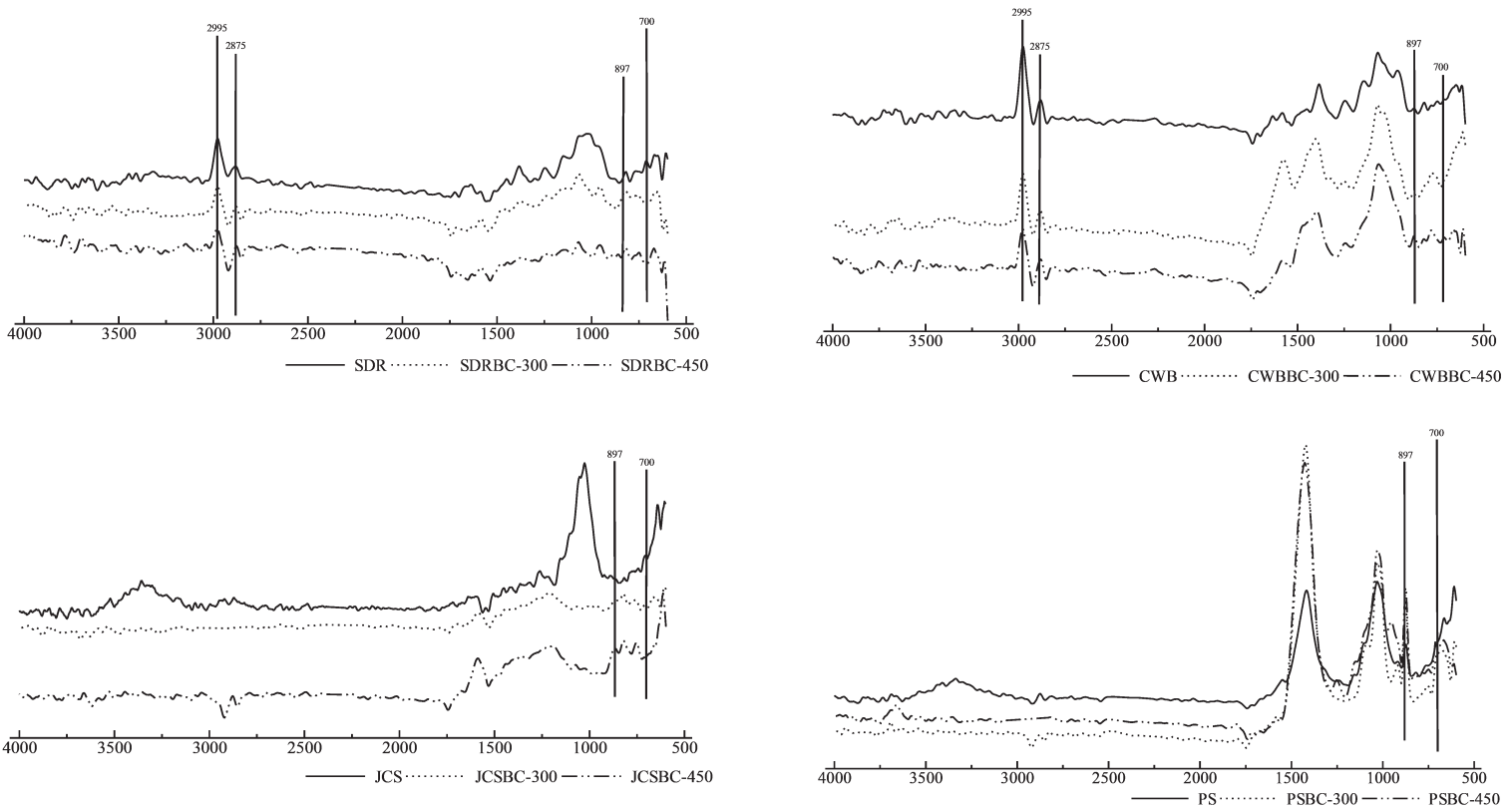

Fig. 1. FTIR analysis of each feedstock and biochar derived at 300 and $450^{\circ} \mathrm{C}$ of carbonization temperature.

Table 4. Elemental analysis of each biochar

\begin{tabular}{|c|c|c|c|c|c|}
\hline Specimen $^{1)}$ & $\mathrm{C}(\%)$ & $\mathrm{N}(\%)$ & S (\%) & $\mathrm{H}(\%)$ & $\mathrm{O}^{2)}(\%)$ \\
\hline SDRBC-200 & $51.91(6.71)^{\mathrm{a} 33}$ & $3.17(0.89)^{\mathrm{a}}$ & $0.10(0.08)^{\mathrm{a}}$ & $4.77(1.52)^{\mathrm{b}}$ & $40.05(9.21)^{\mathrm{d}}$ \\
\hline SDRBC-300 & $65.54(0.15)^{\mathrm{c}}$ & $4.44(0.05)^{\mathrm{b}}$ & $0.54(0.51)^{\mathrm{b}}$ & $4.47(0.06)^{\mathrm{b}}$ & $25.02(0.64)^{\mathrm{b}}$ \\
\hline SDRBC-350 & $65.90(0.71)^{c}$ & $4.43(0.08)^{\mathrm{b}}$ & $0.11(0.02)^{\mathrm{a}}$ & $3.87(0.02)^{\mathrm{ab}}$ & $25.69(0.83)^{\mathrm{b}}$ \\
\hline SDRBC-450 & $69.49(0.75)^{c}$ & $4.66(0.14)^{b}$ & $0.02(0.02)^{\mathrm{a}}$ & $2.95(0.03)^{\mathrm{a}}$ & $22.88(0.97)^{\mathrm{a}}$ \\
\hline
\end{tabular}

1) see Table $3^{1)}$

2) $\mathrm{O}(\%)=100-(\mathrm{C}+\mathrm{N}+\mathrm{S}+\mathrm{H})$

${ }^{3)}$ Mean (standard deviation) with the different superscripts at the same specimen is significantly different $(p<0.05)$ by Duncan's multiple range tests 
Table 5. Physical properties of biochar culture media

\begin{tabular}{ccccc}
\hline \multirow{2}{*}{$\begin{array}{c}\text { Culture media } \\
\text { (Substance + Peat) }\end{array}$} & \multicolumn{4}{c}{ Physical properties $^{2)}$} \\
\cline { 2 - 5 } Perlite + Peat & $9.03(2.03)^{\mathrm{a} 2)}$ & $65.88(3.55)^{\mathrm{c}}$ & $72.74(1.33)^{\mathrm{b}}$ & $0.13(0.01)^{\mathrm{bc}}$ \\
\hline SDRBC-200 + Peat & $11.11(0.14)^{\mathrm{b}}$ & $61.87(2.13)^{\mathrm{a}}$ & $71.08(1.55)^{\mathrm{a}}$ & $0.12(0.01)^{\mathrm{b}}$ \\
SDRBC-250 + Peat & $12.14(2.40)^{\mathrm{c}}$ & $62.94(3.64)^{\mathrm{b}}$ & $72.09(1.37)^{\mathrm{b}}$ & $0.12(0.01)^{\mathrm{b}}$ \\
SDRBC-300 + Peat & $12.30(3.26)^{\mathrm{c}}$ & $62.86(1.71)^{\mathrm{b}}$ & $72.66(1.54)^{\mathrm{b}}$ & $0.13(0.01)^{\mathrm{bc}}$ \\
SDRBC-350 + Peat & $12.21(1.42)^{\mathrm{c}}$ & $62.54(3.70)^{\mathrm{b}}$ & $72.84(1.65)^{\mathrm{b}}$ & $0.13(0.01)^{\mathrm{bc}}$ \\
SDRBC-400 + Peat & $12.75(0.68)^{\mathrm{c}}$ & $62.23(5.10)^{\mathrm{b}}$ & $73.44(2.09)^{\mathrm{c}}$ & $0.14(0.01)^{\mathrm{c}}$ \\
SDRBC-450 + Peat & $12.19(0.54)^{\mathrm{c}}$ & $62.74(4.31)^{\mathrm{b}}$ & $73.12(2.10)^{\mathrm{c}}$ & $0.14(0.01)^{\mathrm{c}}$ \\
\hline CWBBC-450 + Peat & $12.67(1.56)^{\mathrm{c}}$ & $62.83(3.37)^{\mathrm{b}}$ & $73.34(1.21)^{\mathrm{c}}$ & $0.15(0.01)^{\mathrm{d}}$ \\
JCSBC-450 + Peat & $13.79(1.27)^{\mathrm{c}}$ & $63.07(3.08)^{\mathrm{b}}$ & $74.01(2.33)^{\mathrm{c}}$ & $0.15(0.01)^{\mathrm{d}}$ \\
PSBC-450 + Peat & $12.05(1.33)^{\mathrm{c}}$ & $62.89(3.35)^{\mathrm{b}}$ & $72.76(2.36)^{\mathrm{b}}$ & $0.13(0.01)^{\mathrm{bc}}$ \\
\hline
\end{tabular}

\footnotetext{
1) Each biochar was $15 \%$ of ground substance $+85 \%$ of Peat at $v / v \%$

${ }^{2)}$ Physical properties, including AFP: Air-filled porosity; CC: Container capacity; TP: Total porosity; BD: Bulk density

${ }^{3)}$ Mean (standard deviation) at the same specimen with Perlite + Peat is significantly different $(p<0.05)$ by Duncan's multiple range tests
}

above the carbonization temperature of $300^{\circ} \mathrm{C}$. The $\mathrm{H}$ content was $2.95-4.77 \%$, which decreased as the carbonization temperature increased. Delfine et al., (2001) indicates that $\mathrm{N}$ is one of the constituents of organic compounds in a plant. The organic compounds include amino acid, protein, coenzyme, nucleic acid, and chlorophyll. The primary function of $\mathrm{S}$ is to take part in the synthesis of some organic compounds in the plant, such as amino acid, protein, coenzyme A, and partial vitamins. Together with carbon, $\mathrm{H}$ composes the organic matter in a plant, and it plays an important role in the cation exchange between the plant root system and soil particles. $\mathrm{O}$ is one of the compositions of organic matter in a plant, which plays an important role in the anion exchange between the plant root system and soil particles, and acts as the intermediate acceptor of hydrogen ions when the plant performs aerobic respiration. Therefore, when biochar is used as a portion of medium for cultivating plants, it is highly correlated with the elements in the products of high and low carbonization temperature pyrolysis in the degree of nutrient preservation.

Figure 1 shows the FTIR of the various feedstocks and biochars derived at carbonization temperatures of 300 and $450^{\circ} \mathrm{C}$. According to the results of the various feedstocks, the vibration absorption band of the hydroxyl group occurs at $3000-3600 \mathrm{~cm}^{-1}$; the vibration peaks of $\mathrm{CH}$ and $\mathrm{CH}_{2}$ occur at $2850-3000 \mathrm{~cm}^{-1}$; the carbohydrate characteristic absorption peaks are at $1736 \mathrm{~cm}^{-1}$, $1370 \mathrm{~cm}^{-1}$, and $897 \mathrm{~cm}^{-1}$; the aromatic compound characteristic absorption peaks of lignin are at $1510 \mathrm{~cm}^{-1}$, $1453 \mathrm{~cm}^{-1}$, and $1232 \mathrm{~cm}^{-1}$ (Yamada and Ono, 1999). The characteristic absorption peak of the $\beta$-anomeric linkage in the cellulose glucose structure is at $897 \mathrm{~cm}^{-1}$ (Chang et al., 1998). The broadband had many small peaks at $3000-3700 \mathrm{~cm}^{-1}$ due to the $\mathrm{OH}$ functional group, SDR and CWB had a small frequency band at 2700-
$3000 \mathrm{~cm}^{-1}$. The peaks $2875 \mathrm{~cm}^{-1}$ and $2995 \mathrm{~cm}^{-1}$ were in the $\mathrm{C}-\mathrm{H}$ stretching vibration hydrophilic functional group. Schmidt and Noack (2000) indicates that, if biochar is used during the plant growing soil to hold moisture, the hydrophilic functional group is suitable, and the peaks are at $700 \mathrm{~cm}^{-1}, 897 \mathrm{~cm}^{-1}, 2875 \mathrm{~cm}^{-1}$, and $2995 \mathrm{~cm}^{-1}$. According to Figure 1, SDRBC, CWBBC, JCSBC, and PSBC had the $\mathrm{C}-\mathrm{H}$ deformation vibration hydrophilic functional group at $700 \mathrm{~cm}^{-1}$ and $897 \mathrm{~cm}^{-1}, 2875 \mathrm{~cm}^{-1}$ and $2995 \mathrm{~cm}^{-1}$, but the hydrophilic functional group at $2875 \mathrm{~cm}^{-1}$ and $2995 \mathrm{~cm}^{-1}$ was not detected in JCSBC or PSBC. The SDRBC and CWBBC might; therefore, have better water retention than JCSBC and PSBC.

\section{Physicochemical properties of various biochar media}

Physical properties

Table 5 shows the physical properties of the culture media mix of SDRBC and peat at different carbonization temperatures. The AFP, CC, TP, and BD of the culture media were perlite and peat (control group) were 9.03, $65.88,72.74 \%$, and $0.13 \mathrm{~g} / \mathrm{cm}^{3}$, respectively. When the culture media were SDRBC and peat, the AFP was 11.11-12.75\%. According to Duncan's multiple range tests, the SDRBC (at different temperature) and control group had significant difference; CC was 61.87-62.94\%; TP and BD were respectively $71.08-73.44 \%$ and 0.12 $0.14 \mathrm{~g} / \mathrm{cm}^{3}$.

The results of statistical analysis showed that, the perlite and SDRBC media conform to the requirements for general perfect medium, the AFP is $10-25 \%, \mathrm{CC}$ is 40-60\%, TP is 54-80\% (Bunt, 1991; Bures et al., 1991; Fonteno, 1996), and the various biochars have the same trend. Fonteno (1996) indicates that the culture medium particle size is directly correlated with the air permeability and water-holding capacity of the culture medium. When there are a lot of coarse particles, there are a lot 
of non-capillary pores in the culture medium, and air permeability is enhanced; however, the moisture is likely to be lost through the pores, reducing the water-holding capacity. When there are a lot of fine particles, there are a lot of capillary pores in the culture medium, and the water-holding capacity is enhanced. The TP is the sum of AFP and CC; as a medium with large pores contributes to increasing the oxygen diffusion rate, the crops obtain more oxygen. The smaller the container (plug) for cultivating plants, the stricter the requirement for pores; otherwise, the stuffiness during watering is likely to cause poor growth of the plant root. According to the aforesaid results, the AFP, CC, and TP of various biochars and control group conform to the general perfect medium; whereas, BD is a little lower than the perfect medium range $0.30-0.75 \mathrm{~g} / \mathrm{cm}^{3}$ (Gabriels and Vrdonck, 1991).

\section{Chemical properties}

Table 6 shows the $\mathrm{pH}$ changed of various culture media in the cucumber plug seedling period. In the initial seedling period (Day 0), in terms of the $\mathrm{pH}$ of the culture medium mix of biochar or perlite and peat, the $\mathrm{pH}$ of the culture medium with perlite was 6.34 , that with SDRBC200 to SDRBC450 was 6.39-6.78, and that with CWBBC450, JCSBC450, and PSBC450 was 6.87, 6.75 , and 6.83 , respectively. The results are close to the pH 6.5 of the general perfect medium (Joseph et al., 2010). According to the results of Day 28 of the seedling period, the $\mathrm{pH}$ of the medium with perlite was 6.28 , that with SDRBC was 6.58-7.28, and that with WBBC450, JCSBC450, and PSBC450 was 6.87, 7.23, and 7.31, respectively. Lin et al. (2011) reports that the $\mathrm{pH}$ of the culture medium irrigated with bamboo vinegar is lower than that of the culture medium not irrigated, thus, $10^{4}$ diluted bamboo vinegar can effectively reduce the $\mathrm{pH}$ of the culture medium. In the seedling period, the medium was irrigated with $500 \mathrm{~mL}$ of $10^{4}$ diluted bamboo vinegar every three days. The results in Table 6 indicated that the $\mathrm{pH}$ of the biochar as a partial culture medium in the seedling period can be effectively controlled.

Generally, the EC represents the amount of soluble salts in the culture medium solution. A higher value represents a higher nutrient content. If the EC is too high, the culture medium contains much soluble salts, the osmotic pressure is high, and the plants find it difficult to absorb moisture and nutrients (Delfine et al., 2001). The comfort range of the EC of the fruit vegetable culture medium is $1.0-4.0 \mathrm{ds} / \mathrm{m}$ (Norrie et al., 1994). The EC of the general plug culture medium should be lower than $1.0 \mathrm{ds} / \mathrm{m}$ (Koranski, 1993). The initial EC of various culture media in the cucumber plug seedling period (Day 0). The EC of a medium with perlite (control group) was $1.02 \mathrm{ds} / \mathrm{m}$, that with SDRBC derived at different temperatures was $1.02-1.10 \mathrm{ds} / \mathrm{m}$, and that with CWBBC450, JCSBC450, and PSBC450 were 1.22, 1.01, and $0.96 \mathrm{ds} / \mathrm{m}$, declining markedly compared with the initial value as the seedling period extends to $7,14,21$, to 28 days (results not shown in Table). It may be because the soluble salts are released or almost exhausted by the plants, namely, the concentration of soluble salts decreases (Lin et al., 2011). However, on Day 28 after seeding, the EC of various culture media increases slightly, which may be because the hemicellulose, cellulose, and lignin in the culture media are decomposed slowly (Raig, 1998).

The CEC is closely related to the nutrient preserving capability of the medium. The organic matter in the culture medium is negatively charged, absorbing cations, such as ammonium nitrogen, $\mathrm{K}, \mathrm{Ca}, \mathrm{Mg}$, and $\mathrm{Fe}$, reducing the loss of cations. A high CEC represents high nutrient preserving capability (Lemaire, 1995). Regarding the CEC of a culture media with different biochars in the cucumber plug seedling period; on Day 7 of the seedling period, that of the medium with perlite was $51.91 \mathrm{cmol} /$ $\mathrm{kg}$, that of SDRBC derived at different temperatures was $50.16-60.51 \mathrm{cmol} / \mathrm{kg}$, and that with CWBBC450,

Table 6. $\mathrm{pH}$ value of different biochar cultural media during cucumber plug seedling period

\begin{tabular}{cccccc}
\hline \multirow{2}{*}{$\begin{array}{c}\text { Culture media }{ }^{1)} \\
\text { (Substance + Peat) }\end{array}$} & \multicolumn{5}{c}{ Day of seedling period (in days) } \\
\cline { 2 - 6 } & 0 & 7 & 14 & 21 & 28 \\
\hline Perlite + Peat & $6.34(0.02)^{\mathrm{c} 2)}$ & $6.27(0.01)^{\mathrm{b}}$ & $6.22(0.05)^{\mathrm{a}}$ & $6.19(0.02)^{\mathrm{a}}$ & $6.28(0.02)^{\mathrm{b}}$ \\
\hline SDRBC-200 + Peat & $6.45(0.07)^{\mathrm{a}}$ & $6.49(0.03)^{\mathrm{a}}$ & $6.51(0.11)^{\mathrm{a}}$ & $6.43(0.09)^{\mathrm{a}}$ & $6.58(0.04)^{\mathrm{b}}$ \\
SDRBC-250 + Peat & $6.39(0.07)^{\mathrm{a}}$ & $6.59(0.11)^{\mathrm{bc}}$ & $6.43(0.06)^{\mathrm{ab}}$ & $6.61(0.06)^{\mathrm{bc}}$ & $6.73(0.13)^{\mathrm{c}}$ \\
SDRBC-300 + Peat & $6.55(0.10)^{\mathrm{b}}$ & $6.68(0.06)^{\mathrm{b}}$ & $6.62(0.13)^{\mathrm{b}}$ & $6.38(0.09)^{\mathrm{a}}$ & $6.68(0.11)^{\mathrm{b}}$ \\
SDRBC-350 + Peat & $6.64(0.11)^{\mathrm{b}}$ & $6.96(0.03)^{\mathrm{c}}$ & $6.88(0.12)^{\mathrm{bc}}$ & $6.48(0.03)^{\mathrm{a}}$ & $7.04(0.05)^{\mathrm{c}}$ \\
SDRBC-400 + Peat & $6.78(0.13)^{\mathrm{b}}$ & $7.04(0.04)^{\mathrm{c}}$ & $7.11(0.10)^{\mathrm{c}}$ & $6.37(0.06)^{\mathrm{a}}$ & $7.11(0.13)^{\mathrm{c}}$ \\
SDRBC-450 + Peat & $6.76(0.07)^{\mathrm{a}}$ & $6.92(0.10)^{\mathrm{ab}}$ & $7.21(0.03)^{\mathrm{b}}$ & $6.87(0.15)^{\mathrm{a}}$ & $7.28(0.08)^{\mathrm{b}}$ \\
\hline CWBBC450 + Peat & $6.87(0.05)^{\mathrm{a}}$ & $6.94(0.08)^{\mathrm{ab}}$ & $7.08(0.13)^{\mathrm{b}}$ & $7.11(0.02)^{\mathrm{b}}$ & $6.87(0.05)^{\mathrm{a}}$ \\
JCSBC450 + Peat & $6.75(0.12)^{\mathrm{a}}$ & $6.87(0.07)^{\mathrm{b}}$ & $7.17(0.03)^{\mathrm{c}}$ & $7.21(0.09)^{\mathrm{c}}$ & $7.23(0.11)^{\mathrm{c}}$ \\
PSBC450 + Peat & $6.83(0.02)^{\mathrm{a}}$ & $7.20(0.09)^{\mathrm{c}}$ & $6.91(0.06)^{\mathrm{a}}$ & $7.29(0.13)^{\mathrm{c}}$ & $7.31(0.10)^{\mathrm{c}}$ \\
\hline${ }^{1)}$ see Table 5 ${ }^{1)}$ & & & &
\end{tabular}


JCSBC450, and PSBC450 were 50.94, 52.13, and $51.00 \mathrm{cmol} / \mathrm{kg}$, respectively. The maximum CEC occurred in SDRBC450, and statistical analysis of perlite, SDRBC450, CWBBC450, JCSBC450, and PSBC450 showed that SDRBC450 was significantly different from the other four (Table 7). The result of Day 28 of the seedling period shows that the medium with SDRBC400 had the maximum CEC value, and there were significant differences among the biochars derived at $450^{\circ} \mathrm{C}$. Helling et al. (1964) indicates that the proportion of CEC in the soil from organic matter increases with the $\mathrm{pH}$. A comparison between this result and Table 6 showed that the $\mathrm{pH}$ increased, and the plants still grow well in a wide CEC range. However, an appropriate medium CEC makes the plant cultivation management easier (Bunt, 1991).
Chan et al. (2007) indicates that biochar is a soil improvement material with low nutrient content, as compared to other organic materials. However, when soil is mixed with biochar, the water retention and nutrient preserving capability of the soil can be effectively improved, and the soil carbon sequestration capacity is enhanced, thus, the pores (Yu et al., 2007) and functional groups (Figure 1) have better physicochemical absorption, and the nutrients in the culture medium can be relatively retained.

\section{Growth quality of plug seedling}

The results of seedling index I and II of various culture media of biochar, as derived at the carbonization temperature of $450^{\circ} \mathrm{C}$ in the cucumber plug seedling

Table 7. CEC of different biochar cultural media during cucumber plug seedling period

Unit: $\mathrm{cmol} / \mathrm{kg}$

\begin{tabular}{|c|c|c|c|c|c|}
\hline \multirow{2}{*}{$\begin{array}{l}\text { Culture media }{ }^{1)} \\
\text { (Ground substance }+ \text { Peat) }\end{array}$} & \multicolumn{5}{|c|}{ Day of seedling period (in days) } \\
\hline & 0 & 7 & 14 & 21 & 28 \\
\hline Perlite + Peat & $42.75(7.38)^{\mathrm{aA} 2)}$ & $51.91(3.49)^{\mathrm{aA}}$ & $52.86(8.22)^{\mathrm{aA}}$ & $56.59(9.15)^{\mathrm{aA}}$ & $60.89(7.09)^{\mathrm{aA}}$ \\
\hline SDRBC-200 + Peat & $43.82(4.05)^{\mathrm{a}}$ & $57.81(5.83)^{\mathrm{ab}}$ & $64.62(2.45)^{\mathrm{ab}}$ & $66.57(9.52)^{\mathrm{ab}}$ & $73.47(9.57)^{\mathrm{b}}$ \\
\hline SDRBC-250 + Peat & $43.71(2.54)^{\mathrm{a}}$ & $50.16(3.58)^{\mathrm{a}}$ & $59.17(6.25)^{\mathrm{ab}}$ & $65.36(8.10)^{\mathrm{ab}}$ & $70.29(1.66)^{\mathrm{b}}$ \\
\hline SDRBC-300 + Peat & $46.96(6.17)^{\mathrm{a}}$ & $55.78(5.64)^{\mathrm{ab}}$ & $65.57(2.19)^{\mathrm{ab}}$ & $68.11(9.40)^{\mathrm{ab}}$ & $75.37(4.68)^{\mathrm{b}}$ \\
\hline SDRBC-350 + Peat & $48.22(3.12)^{\mathrm{b}}$ & $55.32(6.00)^{\mathrm{ab}}$ & $64.36(8.38)^{\mathrm{ab}}$ & $69.44(6.63)^{\mathrm{ab}}$ & $77.55(5.44)^{\mathrm{b}}$ \\
\hline SDRBC-400 + Peat & $47.33(0.76)^{\mathrm{ab}}$ & $57.43(4.31)^{\mathrm{b}}$ & $65.29(5.79)^{\mathrm{b}}$ & $70.49(5.16)^{\mathrm{bc}}$ & $80.13(2.09)^{c}$ \\
\hline SDRBC-450 + Peat & $48.14(5.19)^{\mathrm{bB}}$ & $60.51(4.39)^{\mathrm{bB}}$ & $62.36(6.32)^{\mathrm{bB}}$ & $72.82(0.62)^{\mathrm{bcB}}$ & $79.46(3.43)^{\mathrm{cB}}$ \\
\hline CWBBC450 + Peat & $42.38(1.21)^{\mathrm{aA}}$ & $50.94(6.76)^{\mathrm{abA}}$ & $58.43(1.10)^{\mathrm{bAB}}$ & $61.95(6.15)^{\mathrm{bA}}$ & $65.43(1.92)^{\mathrm{bA}}$ \\
\hline JCSBC450 + Peat & $43.89(3.59)^{\mathrm{aA}}$ & $52.13(4.31)^{\mathrm{abA}}$ & $59.86(6.29)^{\mathrm{bAB}}$ & $62.34(0.98)^{\mathrm{bA}}$ & $65.89(3.48)^{\mathrm{bA}}$ \\
\hline PSBC450 + Peat & $41.92(4.37)^{\mathrm{aA}}$ & $51.00(3.43)^{\mathrm{abA}}$ & $57.12(3.67)^{\mathrm{bAB}}$ & $62.73(4.73)^{\mathrm{bA}}$ & $64.31(2.89)^{\mathrm{bA}}$ \\
\hline
\end{tabular}

1) see Table $5^{1)}$

${ }^{2)}$ Mean (standard deviation) with the different small alphabets at the specimen and Perlite + Peat, and the different large alphabets at the specimen with $450{ }^{\circ} \mathrm{C}$ of carbonization temperature and Perlite + Peat is significantly different $(p<0.05)$ by Duncan's multiple range tests

Table 8. Seedling index of different biochar cultural media during cucumber plug seedling period

\begin{tabular}{|c|c|c|c|c|c|c|c|c|}
\hline \multirow{3}{*}{$\begin{array}{c}\begin{array}{c}\text { Culture media } \\
\text { (S) }\end{array} \\
\text { (Substance + Peat) }\end{array}$} & \multicolumn{8}{|c|}{ Day of seedling period (in days) } \\
\hline & \multicolumn{2}{|c|}{7} & \multicolumn{2}{|c|}{14} & \multicolumn{2}{|c|}{21} & \multicolumn{2}{|c|}{28} \\
\hline & I & II & I & II & I & II & I & II \\
\hline Perlite + Peat & $\begin{array}{c}0.0159 \\
(0.0014)^{\mathrm{aB2} 2}\end{array}$ & $\begin{array}{c}0.0221 \\
(0.0028)^{\mathrm{aB}}\end{array}$ & $\begin{array}{c}0.0468 \\
(0.0066)^{\mathrm{aA}}\end{array}$ & $\begin{array}{c}0.0992 \\
(0.0128)^{\mathrm{aA}}\end{array}$ & $\begin{array}{l}0.0982 \\
(0.0197)^{\mathrm{aAB}}\end{array}$ & $\begin{array}{l}0.2128 \\
(0.0383)^{\mathrm{aAB}}\end{array}$ & $\begin{array}{c}0.1379 \\
(0.0178)^{\mathrm{aB}}\end{array}$ & $\begin{array}{c}0.2790 \\
(0.0412)^{\mathrm{aA}}\end{array}$ \\
\hline SDRBC-450 + Peat & $\begin{array}{c}0.0230 \\
(0.0041)^{\mathrm{bC}}\end{array}$ & $\begin{array}{c}0.0401 \\
(0.0068)^{\mathrm{bD}}\end{array}$ & $\begin{array}{c}0.0590 \\
(0.0048)^{\mathrm{bB}}\end{array}$ & $\begin{array}{c}0.1341 \\
(0.0141)^{\mathrm{bB}}\end{array}$ & $\begin{array}{c}0.1230 \\
(0.0128)^{\mathrm{aC}}\end{array}$ & $\begin{array}{c}0.2435 \\
(0.0131)^{\mathrm{bB}}\end{array}$ & $\begin{array}{c}0.1654 \\
(0.0552)^{\mathrm{bC}}\end{array}$ & $\begin{array}{c}0.3376 \\
(0.0942)^{\mathrm{bB}}\end{array}$ \\
\hline CWBBC450 + Peat & $\begin{array}{c}0.0116 \\
(0.0012)^{\mathrm{A}}\end{array}$ & $\begin{array}{c}0.0162 \\
(0.0018)^{A}\end{array}$ & $\begin{array}{c}0.0463 \\
(0.0045)^{\mathrm{A}}\end{array}$ & $\begin{array}{c}0.0873 \\
(0.0097)^{A}\end{array}$ & $\begin{array}{c}0.0799 \\
(0.0052)^{\mathrm{A}}\end{array}$ & $\begin{array}{c}0.2032 \\
(0.0097)^{\mathrm{AB}}\end{array}$ & $\begin{array}{c}0.1379 \\
(0.0185)^{\mathrm{B}}\end{array}$ & $\begin{array}{c}0.2756 \\
(0.0508)^{\mathrm{A}}\end{array}$ \\
\hline JCSBC450 + Peat & $\begin{array}{c}0.0208 \\
(0.0024)^{\mathrm{C}}\end{array}$ & $\begin{array}{c}0.0307 \\
(0.0032)^{\mathrm{C}}\end{array}$ & $\begin{array}{c}0.0495 \\
(0.0059)^{\mathrm{A}}\end{array}$ & $\begin{array}{c}0.0969 \\
(0.0058)^{\mathrm{A}}\end{array}$ & $\begin{array}{c}0.1074 \\
(0.0062)^{\mathrm{BC}}\end{array}$ & $\begin{array}{c}0.1689 \\
(0.0209)^{A}\end{array}$ & $\begin{array}{c}0.1260 \\
(0.0214)^{\mathrm{AB}}\end{array}$ & $\begin{array}{c}0.2467 \\
(0.0269)^{\mathrm{A}}\end{array}$ \\
\hline PSBC450 + Peat & $\begin{array}{c}0.0146 \\
(0.0031)^{\mathrm{AB}}\end{array}$ & $\begin{array}{c}0.0208 \\
(0.0042)^{\mathrm{B}}\end{array}$ & $\begin{array}{c}0.0497 \\
(0.0118)^{\mathrm{AB}}\end{array}$ & $\begin{array}{c}0.1000 \\
(0.0224)^{A}\end{array}$ & $\begin{array}{c}0.1053 \\
(0.0198)^{\mathrm{BC}}\end{array}$ & $\begin{array}{c}0.2169 \\
(0.0424)^{\mathrm{B}}\end{array}$ & $\begin{array}{c}0.0995 \\
(0.0362)^{\mathrm{A}}\end{array}$ & $\begin{array}{c}0.2213 \\
(0.0765)^{\mathrm{A}}\end{array}$ \\
\hline
\end{tabular}

1) see Table $5^{1)}$

2) Mean (standard deviation) with the different small alphabets at the Perlite + Peat and SDRAC450+Peat, and the different large alphabets at the specimen with 450 oC of carbonization temperature and Perlite + Peat is significantly different $(p<0.05)$ by Duncan's multiple range tests 
period, are shown in Table 8. The seedling index I of the medium with perlite was 0.0159 on Day 7 of the seedling period; and that with SDRBC450 was 0.0230; that with CWBBC450, JCSBC450, and PSBC450 was 0.116, 0.0208, and 0.0146 , respectively., the medium with perlite was significantly different from that with SDR-450, and that with perlite was not different from SDRBC450 and JCSBC450 with biochars derived at $450^{\circ} \mathrm{C}$; however, the CWBBC450 had the minimum index, according to Duncan's multiple range tests. In terms of the seedling index I on Day 21 and Day 28 of the seedling period, the seedling index of various culture media was markedly increased, and SDRBC450 was the best.

The seedling index I took the stem diameter, stem length, and dry weight of the whole plant as the evaluation items. The fresh weight of underground part and fresh weight of above-ground part were put into the calculation basis of this study, which was seedling index II, according to which, the effect of various culture media on the growth quality of cucumber was evaluated. The results are also as shown in Table 8. The seedling index of the medium with perlite was 0.0221 on Day 7 of the seedling period; that of SDRBC450 was 0.0401; and that of the other three was respectively 0.0162, 0.0307, and 0.0208. According to Duncan's multiple range tests, the medium with perlite was significantly different from SDR450, the SDRBC450 was also the best, and that with perlite and $450^{\circ} \mathrm{C}$ biochar. SDRBC450 were different from others; however, that with perlite was insignificantly from PSBC450, and CWBBC450 was the minimum. For the seedling index II on Day 28 of the seedling period, it with perlite was 0.2790 , SDRBC450 was 0.3376 ; and CWBBC450, JCSBC450, and PSBC450 were 0.2756, 0.2467 , and 0.2213 . The seedling index II of various culture media was markedly increased. According to statistical analysis, SDRBC450 was significantly different from perlite, CWBBC450, JCSBC450, and PSBC450.

\section{CONCLUSION}

This study used four types of AFPW to prepare different biochars, and investigate the effect as the portion of culture mediums on vegetable plug seedling quality. The elements analysis of the feedstocks showed that the $\mathrm{C}, \mathrm{N}$, and $\mathrm{H}$ contents were 32.14-50.99, 0.04-3.31, and 3.85-6.63\%. The holocellulose, lignin, alcohol-toluene extractives, and ash contents were 32.30-68.40, 16.50$34.63,1.59-13.12$, and $0.63-7.73 \%$. The yield of biochar derived at different carbonization temperatures decreased as the temperature increased, whereas, the $\mathrm{pH}$ and iodine value increased with the temperature. The elements analysis of various biochars showed that JCSBC has the highest C content, followed by SDRBC, but SDRBC had the highest $\mathrm{N}$ content. The FTIR results show that $\mathrm{C}-\mathrm{H}$ stretching vibration hydrophilic functional groups at $2875 \mathrm{~cm}$ and $2995 \mathrm{~cm}^{-1}$ in the spectrum were undetected in the spectrum of JCSBC and PSBC. The physicochemical properties of culture medium with biochar were close to the requirements for the general perfect medium. According to the seedling biomass investigation, on Day 28 after seeding, SDRBC450 had maximum sound seedling indexes I and II, and was significantly different from perlite, CWBBC450, JCSBC450, and PSBC450. In the scope of this study, the physicochemical properties of the SDRBC450 as the portion of culture medium and the mixture of $15 \%$ biochar and peat were better than the perlite only and the other three biochars with peat and, thus seedling growth quality was better.

\section{ACKNOWLEDGEMENTS}

The authors are grateful to the K Liquor Inc., Sinshe Township, Taichung County, woodworking factory, NCYU and Cheng Loong Pulp, Taiwan for providing the experimental materials, sorghum distillery residue, cultivation waste bag, Japanese cedar thinning sawdust, and pulp sludge.

\section{AUTHOR CONTRIBUTION}

Wei-Ru KUO performed the experiments, analyzed the data and the statistical analysis. Jian-Jhong HUANG assisted the experiments. Noboru FUJIMOTO participated in the design of the study and supervised the works. Han Chien LIN designed this study and wrote the paper. The authors assisted in editing of the manuscript and approved the final version.

\section{REFERENCES}

Agricultural statistics 2012 Council of Agriculture, Executive Yuan, Taiwan, ROC

Awika, J. M. and L. W. Rooney 2004 Sorghum phytochemicals and their potential impact on human health. Phytochem, 65: 11991221

Balat, M. and G. Ayar 2005 Biomass energy in the world, use of biomass and potential trends. Energy Sources, 27: 931-940

Bilderback, T. E., W. C. Fonteno and D. R. Johnson 1982 Physical properties of media composed of peanut hulls, pine bark, and peatmoss and their effects on Azalea growth. Journal of the American Society for Horticultural Science, 107(3): $522-525$

Bragg, N. C., and B. J. Chambers 1988 Interpretation and advisory applications of compost air-filled porosity (AFP) measurements. Acta Horticulturae, 221: 35-44

Bunt, A. C. 1991 The relationship of oxygen diffusion rate to the air-filled porosity of potting substrates. Acta Horticulturae, 294: $215-222$

Bures, S., F. X. Martinez and N. Perez 1991 Physical properties of substrate mixtures according to the characteristics of the original materials. Acta Horticulturae, 294: 207-214

Carrott P. J. M. and M. M. L. R. Carrott 2007 Lignin-from natural adsorbent to activated carbon: A review. Bioresource Technology, 98: 2301-2312

Chan, K. Y., L. Van Zwieten, I. Medxsros, A. Downie and S. Joseph 2007 Activated values of green wastes biochar as a soil amendment. Australian Journal of soil Research 45: 629-634

Chang, C. F., C. Y. Chang, S. L. Chang, S. Y. Lee and P. C. Wang 1998 Effect of physical carbonization and activation methods on the preparation of activated carbon corn cob. Journal of the Chinese Institute of Environment Engineers, 8: 227-232

Delfine, S., F. Loreto and A. Alvino 2001 Droughtstress effects on physiology, growth and biomass production of rainfed and irrigated bell pepper plants in the Mediterranean region. Journal of the American Society for Horticultural Science, 
126 (3): 297-304

Diao, Y., W. P. Walawender and L. T. Fan 2002 Activated carbons prepared from phosphoric acid activation of grain sorghum. Bioresource technology, 81(1): 45-52

Fonteno, W. C. 1990 Know your media. Growertalks" on plugs. Growertalks magazine. pp. 84-92

Fonteno, W. C. 1996 Growing media: Types and physical/ chemical properties. A Grower's Guide to Water, Media, and nutrition for greenhouse crops. Ball Publishing. pp. 93-122

Glaser, B., J. Lehmann, and W. Zech 2002 Ameliorating physical and chemical properties of highly weathered soils in the tropics with charcoal: a review. Biology and Fertility of Soils, $\mathbf{3 5}$ : 219-230

Gabriels, R. and O. Vrdonck 1991 Physical and chemical characterization of plant substrates:: towards a European standardization. Acta Horticulturae, 294: 249-259

Gundale, M. J. and, T. H. DeLuca 2006 Temperature and source material influence ecological attributes of ponderosa pine and Douglas-fir charcoal. Forest Ecology and Management, 231: 86-93

Helling, C. S., G. Chesters and R. B. Corey 1964 Contribution of organic matter and clay to soil cation exchange capacity as affected by the $\mathrm{pH}$ of the saturation solution. Soil Science Society of America Proceedings, 28: 517-520

Hendershot, W. H. and M. Duquette 1986 A simple barium chloride method for determining cation exchange capacity and exchangeable cations. Soil Science Society of America Journal, 50: 605-608

Hidetoshi, A., B. K. Samson, H. M. Stephan, K. Songyikhangsuthor, H. K. Yoshiyuki, I. Yoshio, S. Tatsuhiko and H. Takeshi 2009 Biochar amendment techniques for upland rice production in Northern Laos 1. Soil physical properties, leaf SPAD and grain yield. Field Crops Research, 111: 81-84

Ho, H M.,W. R. Kuo, C. W. Peng, G. S. Hwang and H. C. Lin 2011 Investigation of yield and seedling growth of cabbage from cultural media with Moso bamboo charcoal. Journal of Agriculture and Forest, NCYU, 10(1): 43-60

Jiang, T. Y., J. Jiang, R. K. Xu and Li, Z. 2012 Adsorption of Pb (II) on variable charge soils amended with rice-straw derived biochar. Chemosphere, 89: 249-256

Joseph, S. D., A. Downite, P. Munroe and J. Lehmann 2007 Biochar for carbon sequestration, reduction of greenhouse gas emissions and enhancement of soil fertility; a review of the materials science. Proceedings of the Australian combustion symposium. Sydney.

Joseph, S. D., M. Camps Arbestain, and Y. Lin 2010 An investigation into the reactions of biochar in soil. Austra. Australian Journal of soil Research, 48: 501-515

Kolodynska, D., R. Wnetrzak, J. J. Leahy, M. H. B. Hayes, W. Kwapinski and Z. Hubicki 2012 Kinetic and adsorptive characterization of biochar in metal ions removal. Chemical Engineering Journal, 197: 295-305

Koranski, D. S. 1993 Plug production technique. Proceedings of $2^{\text {nd }}$ Symposium on Seed Industry and Marketing of Horticultural Crops. pp. 15-27

Lemaire F. 1995 Physical, chemical and biological properties of growing medium. Acta Horticulturae, 396: 273-284

Lehmann, J., and S. Joseph 2009 Chapter 1: Biochar for Environmental Management, Science and Technology. Earthscan Publications Ltd., UK. pp. 1-9
Lin, H. C., Y D. Wu, C. W. Peng, G. S Hwang and W. R. Kuo 2010 Application of Moso bamboo charcoal cultural media to vegetable plug seedlings. Journal of Experimental Forest National Taiwan University, 29(3): 59-171

Lin, H. C., Y. H. Huang, T. R. Tsai, C. W. Peng, G. S. Hwang, and W. R. Kuo 2011 Investigation of promoting growth of Tomato plug seedlings from Moso bamboo charcoal cultural media with bamboo vinegar. Journal of Agriculture and Forest, NCYU, 8 (2): 58-72

Lin, H. C., Y. C. Weng, G. S. Hwang, and N. Fujimoto 2014 Evaluation of adsorption and mutagenicity of activated carbons refined from charcoals. Journal of the Faculty of Agriculture Kyushu University, Japan, 59(1): 117-125

Lua, A. C., T.Yang, and J. Guo 2004 Effects of pyrolysis conditions on the properties of activated carbons prepared from pistachio-nut shells, Journal of Analytical and Applied Pyrolysis, 72: 279-287

Neary, D. G., C. C. Klopatek, L. F. DeBano and P. F. Ffolliott 1999 Fire effects on belowground sustainability: A review and synthesis. Forest Ecology and Management, 122: 51-71

Norrie, J., M. E. D. Graham, J. Charbonneau and A. Gosselin 1994 Impact of irrigation management of greenhouse tomato: yield, nutrition, and salinity of peat substrate. Canadian Journal of Plant Science, 74: 497-503

Peng, C. W. and H. C. Lin 2015 Japanese cedar ash as a natural activating agent for preparing activated carbon. Journal of Wood Science Japan, 61(3): 316-325

Reed A. R. and P. T., Williams 2004 Thermal processing of biomass natural fibre wastes by pyrolysis. International Journal of Energy Research, 28: 131-145

Regmi, P., J. Moscoso, L. Kumar, G. S. Cao, X. J. Mao and G. Schafran 2012 Removal of copper and cadmium from aqueous solution using switch grass biochar produced via hydrothermal carbonization process. Journal of Environment Management, 109: 61-69

Raig, A., A. Lax, J. Cegarra, F. Costa and M. T. Hernandez 1988 Cation exchange capacity as a parameter for measuring the humification degree of manure. Soil Science, 146(5): 311-316

Schmidt, W. M. I. and A. G. Noack 2000 Black carbon in soils and sediments: analysis, distribution, implications, and current challenges. Global Biogeochem, 14: 777-793

Shrestha, G., S. Traina and C. Swanston 2010 Black carbon's properties and role in the environment: a comprehensive review. Sustainability, 2: 294-320

Teng, H. and L. Y. Hsu 1999 High-porosity carbons prepared from bituminous coal with potassium hydroxide activation, Industrial and Engineering Chemistry Research, 38: 2947

Tsakaldimi, M. 2006 Kenaf (Hibiscus cannabinus L.) core and rice hulls as components of container media for growing Pinushalepensis M. seedlings. Bioresource Technology, 97(14): 1631-1639

Walker, P. L. and A. Almagro 1995 Activation of pre-chlorinated anthracite in carbon dioxide and steam. Carbon, 33(2): 239-241

Yamada, T. and H. Ono 1999 Rapid liquefaction of lignocellulosic waste by using ethylene carbonate. Bioresource Technology, 70: $61-67$

Yu, X. Y., G. G. Ying, and R. S. Kookana 2009 Reduced plant uptake of pesticides with biochar additions to soil. Chemosphere, $\mathbf{7 6}$ : $665-671$ 